\title{
Zachowania prozdrowotne studentów Uniwersytetu Trzeciego Wieku w Uniwersytecie Medycznym we Wrocławiu. Wyniki badań i rekomendacje
}

\author{
Health-seeking behaviours of students of the University of the \\ Third Age at Wrocław Medical University. \\ Research results and recommendations
}

Streszczenie. Artykuł ma charakter empiryczny i teoretyczny. Część teoretyczna ogranicza się do definicji zachowań prozdrowotnych, które to stanowią podstawę podjętych badań empirycznych. Całościowe badania miały charakter ilościowy ale i jakościowy. W przedstawionym materiale autorka prezentuje wybrane wyniki badań ilościowych, szukając odpowiedzi na pytania:

- jaki jest profil społeczny studentów-seniorów uczęszczających na zajęcia UTW?

- jakie zachowania prozdrowotne preferują?

Badania przeprowadzono metodą sondażu diagnostycznego, w kwietniu 2017 roku. Wyniki badań wskazują na zróżnicowanie działania seniorów w zakresie troski o zdrowie oraz różnej motywacji podjęcia kształcenia w okresie późnej dorosłości. W sensie projekcyjnym posłużą optymalizacji działań programowych, tym bardziej, że Uniwersytet Trzeciego Wieku w Uniwersytecie Medycznym we Wrocławiu obchodzi w tym roku dopiero pierwszy rok działalności.

Słowa kluczowe: psychologia zdrowia, zachowania prozdrowotne, badania ilościowe, diagnoza społeczna, projektowanie

Summary. The article presents mainly empirical but also theoretical approach. The theoretical part is limited to a definition of health-seeking behaviours, which form the basis for the undertaken empirical research. A comprehensive research was of a quantitative as well as qualitative nature. The author of the study presents selected results of quantitative research which are seeking an answer to questions: 
Third Age?

- what is a social profile of senior students attending classes at the University of the

- which health-seeking behaviours do they prefer?

The research was conducted in April 2017 using methods of diagnostic survey. The results indicate differentiated actions undertaken by senior citizens in relation to healthcare and varied motivations to pursue studies in late adulthood. From the projective point of view, the results serve to optimize programs or curricular activities as the University of the Third Age at the Medical University in Wrocław is celebrating its first year of operation.

Keywords: health psychology, health-seeking behaviours, quantitative research, social diagnosis, projection

\section{Zachowania prozdrowotne - atrybuty pojęcia}

Tematyka zachowań zdrowotnych, a zwłaszcza ich zmian, zajmuje dzisiaj czołowe miejsce na liście przedmiotów badań w psychologii zdrowia. Stanowi ogromne źródło informacji niezbędnych do wprowadzania nowych programów promocji i profilaktyki zdrowia (Heszen, 2007, s. 90-103). Po raz pierwszy termin „zachowania prozdrowotne” został użyty całkiem niedawno, w 1954 roku przez E. Koosa. Pośród wszystkich zachowań zdrowotnych wydziela się dwie główne grupy: (a) działania sprzyjające zdrowiu - szeroko ujmowane zachowania prozdrowotne, tzw. biopozytywne, (b) czynności zagrażające utrzymaniu dobrej kondycji fizycznej - zachowania antyzdrowotne, tzw. bionegatywne (Arendt, Laszczyńska, Bażydło, 2014, s. 659-666). Bardzo duże znaczenie dla postrzegania zachowań prozdrowotnych ma stan zdrowia. Osoby względnie zdrowe z jednaj strony, a z drugiej strony osoby cierpiące na choroby przewlekłe czy nieuleczalne, będą miały inne wyobrażenie o badanym zjawisku. Za zachowania prozdrowotne można uznać wszystkie dążenia, które przyczyniają się do zachowania bądź poprawy ogólnego samopoczucia. To całokształt działań chroniących zdrowie oraz zapobiegających wystąpieniu jego utraty. Wszystkie te czynności można określić jako szeroko rozumianą prewencję pierwotną i wtórną (Smoleń, Gazdowicz, Reut, 2011, s. 5-9). Przejawianie zachowań prozdrowotnych ma ogromy wpływ na pomyślne starzenie się - ang. successful agening. Na działania przyczyniające się do pozyskania, bądź utrzymania dobrego zdrowia składają się:

- $\quad$ zachowania związane ze zdrowiem fizycznym;

- $\quad$ zachowania dotyczące szeroko pojmowanego zdrowia psychospołecznego;

- działania prewencyjne; 
- działania eliminujące czynności zagrażające zdrowiu (Muszalik, 2013, s. 509-513).

Jednym $\mathrm{z}$ atrybutów zachowań prozdrowotnych jest aktywność fizyczna. Wpływa korzystnie na układ kostno-stawowy człowieka, układ nerwowy, układ pokarmowy oraz na pracę układu moczowo-płciowego. Uprawianie sportu oddziaływuje na zdrowie psychiczne, powodując wydzielanie endorfin, opóźnia proces starzenia, powstrzymuje rozwój chorób metabolicznych. Należy wspomnieć, że wykonywanie ćwiczeń fizycznych bezpośrednio zwiększa możliwości funkcjonalne człowieka w okresie późnej dorosłości (Wojtasik, 2015, s. 350-372). Według Polskiego Towarzystwa Kardiologicznego, aby zachować zdrowie, osoba starsza powinna uprawiać umiarkowany wysiłek fizyczny, minimum cztery razy w tygodniu od 30 do 45 minut. Systematycznie przejawiana aktywność fizyczna nosi nazwę treningu medycznego. To „świadomie kierowane działanie, polegające na celowym wykorzystaniu, ściśle określonych co do formy, objętości, intensywności i częstotliwości ćwiczeń fizycznych dla uzyskania efektów fizycznych i psychicznych" (Woynarowska, 2008, s. 51-55).

Kolejnym bardzo ważnym działaniem prozdrowotnym jest racjonalne odżywianie oraz odpowiednia ilość snu. Z upływem lat metabolizm człowieka spowalnia, co za tym idzie dieta seniora powinna ograniczać ilość spożywanych kalorii. Odżywianie zgodne z zaleceniami „piramidy żywienia” przyczynia się do zwiększenia odporności oraz zachowania sprawności fizycznej. Osoba dorosła powinna spożywać trzy posiłki dziennie w odstępach czasowych od 4 do 5 godzin, w miarę o stałych porach dniach z odpowiednią regularnością (Tańska, 2013, s. 915-918). Sen natomiast jest jedną z podstawowych potrzeb biologicznych człowieka. Nieustanna aktywność przez 24 godziny wpływa niekorzystnie na procesy psychiczne zachodzące w mózgu człowieka (48 godzin bezustannej pracy powoduje znaczne obniżenie zdolności percepcyjnych, przyczynia się do powstawania depresji oraz może być powodem agresji). Zdrowie psychiczne to przede wszystkim umiejętność radzenia sobie ze stresem, unikanie sytuacji trudnych do rozwiązania. Pomoc ze strony społeczeństwa wpływa na zwiększenie poczucia własnej wartości, umożliwia skorzystanie z pomocy materialnej oraz pozwala na „buforowanie działań innych ludzi w sytuacjach stresujących" (Ogińska, Zadworna, Rogala, 2015, s. 570-577).

Kolejnym bardzo ważnym zachowaniem prozdrowotnym jest prewencja zdrowia. Korzystanie z szerokiego pakietu badań profilaktycznych oraz genetycznych jest swoistym dowodem troski o zdrowie. 
Nabywanie zachowań prozdrowotnych może odbywać się w dwojaki sposób:

- bezpośrednio, poprzez naukę od rodziców odpowiednich nawyków higienicznych, przejawianych w codziennych czynnościach życiowych;

- pośrednio, poprzez przyjmowanie konkretnych przyzwyczajeń uwarunkowanych przez skład osobowy rodziny (Mróz, Kaleta, 2013, s. 239-246).

Bardzo istotną rolę w przejawianiu zachowań prozdrowotnych odgrywają również mass media. Około $30 \%$ osób w wieku powyżej 65 . roku życia korzysta z Internetu. Polskie Badania Internetu (Raporty i analizy. Polscy internauci) wskazują, że wśród pozyskiwanych informacji dominują dane na temat diagnostyki chorób i ich leczenia, pakiety reklamowe traktujące o zdrowym odżywianiu czy aktywności fizycznej, suplementach diety oraz lekach wydawanych bez recepty (Syrkiewicz, Holecki, 2014, s. 171-176).

\section{Metodologia badań}

Podstawy teoretyczne: badania stanowią element mikrodiagnozy społecznej w zakresie edukacji dorosłych w ujęciu fenomenologicznym;

- Cel badań: opracowanie profilu społecznego studentów-seniorów; badanie występowania zachowań prozdrowotnych oraz ich kategoryzacja w zakresie: samooceny stanu zdrowia, nawyków żywieniowych w zakresie działań profilaktycznych, funkcji poznawczych, aktywności fizycznej, profilaktyki oraz mechanizmów samoregulacyjnych (samoakceptacja);

- Metody i narzędzia badawcze: sondaż diagnostyczny, wywiad narracyjny (zgoda Komisji Bioetycznej przy Uniwersytecie Medycznym we Wrocławiu, luty 2017 rok);

- Procedura badania diagnostyczności narzędzia: w celu zbadania diagnostyczności narzędzia zastosowano wzór alfa Cronbacha i uzyskano w badaniach pilotażowych współczynnik wartości 0,74, który wskazał na poprawność konstrukcyjną i diagnostyczność narzędzia;

- Populacja i jej dobór: 90 osób (studenci Uniwersytetu Trzeciego Wieku przy Uniwersytecie Medycznym we Wrocławiu, którzy zadeklarowali chęć uczestnictwa w badaniach, próba reprezentatywna stanowiąca $75 \%$ ogółu studentów); dobór próby - losowy; 
- Czas i miejsce badań: kwiecień 2017 rok, Centrum Informacji Medycznej Uniwersytetu Medycznego we Wrocławiu.

\section{Wyniki badań i wstępna dyskusja}

\section{Profil społeczny studentów (wybrane kategorie badawcze)}

- Płeć: $90 \%$ kobiety, $10 \%$ mężczyźni;

- Wiek: 60 lat i powyżej - 93\%, 50 lat i powyżej - 7\%;

- Wykształcenie: 54\% wykształcenie wyższe, $43 \%$ wykształcenie średnie, $3 \%$ wykształcenie zawodowe;

- Stan cywilny: $58 \%$ stan wolny, $42 \%$ żyjących w związku;

- Sytuacja finansowa: $18 \%$ zadowalająca sytuacja finansowa, pozwalająca realizować plany i marzenia, $81 \%$ sytuacja finansowa zadowalająca, $1 \%$ sytuacja finansowa bardzo słaba, wystarczająca na przeżycie.

\section{Występowanie zachowań prozdrowotnych}

\section{Ocena indywidualnego stanu zdrowia w percepcji studentów}

W subiektywnej ocenie zdrowia badani studenci seniorzy w większości pozytywnie (99\%) określają obecny stan fizjologiczny z tego 83\% charakteryzuje swoją kondycję zdrowotną jako dość dobrą, natomiast $16 \%$ uważa się za „chodzący” okaz zdrowia. 56\% respondentów przyznało, iż ma świadomość bardzo dużego wpływu na swoją kondycję zdrowotną oraz niemalże tyle samo, (43\%) studentów-seniorów stwierdziło, iż ma świadomość, że ich samopoczucie zależy od nich samych. Dla $92 \%$ respondentów zdrowie jest najcenniejszą wartością w życiu, natomiast $8 \%$ stwierdziło, że preferuje inne wartości, zaprzeczając tym samym tej popularnej tezie. Wartościowanie zdrowia, jako najwyższego dobra w życiu jednostki, przyczynia się w znacznej mierze do podejmowania zachowań prozdrowotnych. Osoba starsza, która przypisuje dużą rangę pomyślnej kondycji fizycznej, posiada większą motywację i chęć do wykonywania działań sprzyjających zachowaniu dobrego ogólnego samopoczucia niż jednostka nieceniąca zdrowia jako najwyższej wartości w życiu. Ustosunkowanie się do zdrowia oraz sposób jego postrzegania ściśle koreluje z przyjmowaniem pozytywnych postaw sprzyjających podejmowaniu zachowań zapobiegających wystąpieniu choroby, czyli wdrażania takich działań w życiu jednostki, które przyczyniają się do zachowania 
dobrej kondycji zarówno fizycznej, ale także psychicznej. 85\% badanych seniorów w swojej samoocenie stwierdziła, że ma świadomość, iż nie podejmując na co dzień należytych działań na rzecz swojej zdrowotności, ma z tego tytułu dyskomfort psychiczny. Natomiast $15 \%$ zadeklarowało, iż nie odczuwa ani potrzeby, ani chęci do wykonywania czynności sprzyjających zdrowiu. $Z$ powyższego można wywnioskować, że osoby starsze uczestniczące w badaniach posiadają znaczną świadomość dobrodziejstw, które niosą ze sobą wszelakie zachowania prozdrowotne. Badając samoocenę w zakresie poziomu wiedzy $51 \%$ badanych uznało, że posiada duży zasób wiedzy dotyczący opisywanego zagadnienia, $49 \%$ ankietowanych uznało, że ich wiedza na temat zachowań prozdrowotnych jest niewystarczająca. To, co dla jednych seniorów wydaje się być oczywiste, dla pozostałych wcale takie nie jest.

\section{Nawyki żywieniowe}

Z wyników badań można wywnioskować, że znaczna większość osób starszych posiada prawidłowe nawyki żywieniowe w postaci konsumpcji, odpowiedniej do wieku, ilości dań w ciągu dnia ( $81 \%$ badanej populacji). Dodatkowo $91 \%$ ankietowanych deklarowało, że zwraca szczególną uwagę również na jakość spożywanych pokarmów. Studenci-seniorzy, potrafią doskonale wykorzystać pozyskaną wiedzę w praktyce, o czym świadczą uzyskane wyniki sondażu. Uniwersytet Trzeciego Wieku poprzez wykłady o tematyce żywności i żywienia przyczynia się w znacznej mierze do upowszechniania zasad dotyczących prawidłowych zachowań żywieniowych, sprzyjających utrzymaniu zdrowia w dobrej kondycji. Tak stwierdziło 30\% badanych. Pomimo przestrzegania ogólnych zasad żywienia niestety duża część respondentów przyznaje do przejadania się (tylko 30\% ankietowanych zadeklarowało, że podczas spożywania posiłków zaspokaja wyłącznie pierwszy głód, 24\% ankietowanych obawia się przybrania większej masy ciała, zaś $18 \%$ stwierdza nieodpartą chęć jedzenia coraz więcej, $28 \%$ pytanych nie udzieliło odpowiedzi).

Kolejne zagadnienie dotyczyło ilości płynów wypijanych w ciągu doby. $43 \%$ respondentów uznało, że codziennie wypija średnio 1,5 litra płynów niegazowanych w postaci wody, soków czy napojów mlecznych. $36 \%$ ankietowanych przyznało, że pije 0,5-1,0 litra takich płynów dziennie. Jedynie $18 \%$ badanych deklarowało wypijanie powyżej 1,5 litra wody, a 3\% studentów seniorów przez cały dzień zażywało mniej niż 0,5 litra napojów niegazowanych. Zbyt małe nawodnienie przyczynia się do osłabienia wydolności fizycznej, znacznie pogarsza stan psychofizyczny jednostki, a także może powodować bezsenność, rozdrażnienie. Dodatkowo pod wpływem małej porcji 
wody wypijanej w ciągu dnia zmniejsza się ilość wydalanego moczu, co warunkuje zmniejszenie liczebności usuwanych zbędnych produktów przemiany materii. Dlatego też należy zwiększyć świadomość studentów seniorów na ten temat.

Ciekawym jest fakt, że spora liczba badanych, bo aż 20\% przyznało, że w ciągu swojego życia stosowało długotrwałe (powyżej 1 miesiąca) diety odchudzające, ale jednocześnie nikt $\mathrm{z}$ tej grupy nie miał kontaktu $\mathrm{z}$ dietetykiem.

\section{Profilaktyka}

- $\quad 69 \%$ respondentów zadeklarowało, że zażywa różnego rodzaju medykamenty w przypadku wystąpienia niedoboru witamin czy minerałów, jednakże aż 31\% przyznało, że nie stosuje dodatkowych suplementów diety;

- jedynie $24 \%$ ankietowanych zakomunikowało, że profilaktycznie zaszczepia się przeciwko grypie, $76 \%$ badanych zadeklarowało brak jakichkolwiek działań w tym kierunku;

- $69 \%$ seniorów poddaje się przynajmniej raz w roku profilaktycznym badaniom specjalistycznym w postaci między innymi: oznaczenia poziomu cholesterolu we krwi, u kobiet badanie piersi, zaś u mężczyzn sprawdzenie wartości PSA; 18\% stwierdziło, że czyni to bardzo często, korzystając ze skierowań różnych specjalistów; $13 \%$ badanych przyznało, że bardzo rzadko korzysta z profilaktycznych czynności diagnostycznych;

- $\quad 27 \%$ badanych zadeklarowało przestrzeganie zaleceń otrzymywanych podczas specjalistycznych konsultacji, a także troski o swoje zdrowie, np. w postaci ubierania się adekwatnie do pogody, 35\% przestrzega wybiórczo zaleceń lekarskich, natomiast $8 \%$ wskazało, że nie chodzi do lekarza, a 30\% uzyskane zalecenia lekarskie konsultuje $\mathrm{z}$ innymi specjalistami.

\section{Aktywność fizyczna}

- $78 \%$ studentów seniorów deklarowało uprawianie różnego rodzaju aktywności ruchowych: z czego $45 \%$ osób w okresie późnej dorosłości na sport poświęca 1-2 dni w tygodniu, $24 \%$ od 3 do 4 dni, a $9 \%$ respondentów oświadcza, że na treningi przeznacza powyżej 4 dni w ciągu całego tygodnia (dominuje jazda na rowerze oraz spacery). $22 \%$ ankietowanych przyznało, że nie podejmuje żadnych form praktyk ruchowych. 
- $\quad 71 \%$ ankietowanych poświęca na sport ponad pół godziny na dobę. Wśród osób aktywnych fizycznie (78\% badanej populacji) prawie co drugi z nich na sport przeznacza powyżej 45 minut na dobę, natomiast $3 \%$ badanych stwierdziło, że ich aktywność fizyczna trwa mniej niż 15 minut dziennie.

- $63 \%$ ankietowanych w subiektywnej samoocenie uznała swoją sprawność ruchową jako dobrą, z czego 5\% przypisała jej bardzo dobrą jakość. Z kolei $44 \%$ badanej populacji stwierdziła, że cechuje się kondycją fizyczną na poziomie dostatecznym, a 14\% charakteryzowała ją jako niską.

- $\quad 92 \%$ respondentów przyznało, że przejawianie aktywności fizycznej przyczynia się do zachowania dobrej kondycji zdrowotnej, zaś $8 \%$ badanych uważało, że aktywność fizyczna jedynie w małym stopniu warunkuje zdrowie.

Zgodnie w powyższym śmiało można wywnioskować, że studenci seniorzy Uniwersytetu Trzeciego Wieku przy Uniwersytecie Medycznym we Wrocławiu podejmują liczne praktyki z zakresu prewencji pierwotnej. Dodatkowo należy stwierdzić, że aktywność fizyczna, jako profilaktyczne działanie sprzyjające zdrowiu, jest mało popularną formą czynności prozdrowotnych. Stąd warto wprowadzić większą ilość prelekcji na temat wpływu ruchu na zdrowie jednostki, aby powiększyć zasób wiedzy w tej problematyce.

\section{Funkcje poznawcze}

Na równi z aktywnością fizyczną studenci cenią, jako wartość najwyższą, sprawność poznawczą. W wyniku wywiadu narracyjnego uzyskano deklaratywne odpowiedzi, iż studenci-seniorzy kładą duży nacisk na czytanie prasy, książek, rozwiązywanie krzyżówek, oglądanie teleturniejów oraz rozwijanie swoich zainteresowań. Nie było to jednak przedmiotem szczegółowej analizy. Warto jednak podkreślić, iż do uczelnianej biblioteki zapisała się w okresie pierwszego roku funkcjonowania UTW tylko jedna osoba (być może słuchacze pozyskują informację z innych źródeł, co stanie się przedmiotem odrębnego opracowania).

83\% studentów seniorów przyznało, że nigdy w przeszłości nie doświadczyło badania sprawności pamięci. Jedynie $17 \%$ badanych osób stwierdziło, iż przeszło badanie w zakresie oceny zdolności procesów myślowych.

W kolejnej części kwestionariusza ankiety respondenci zostali poproszeni o ustosunkowanie się do kwestii snu: 17\% respondentów oświadczyło, że potrzebuje minimum 8 godzin na taką regenerację organizmu, $43 \%$ wszystkich ankietowanych zadeklarowało, iż przesypia 6-7 godzin w ciągu 
doby, 36\% zakomunikowało iż śpi 5-6 godzin, natomiast 4\% poświęca na sen mniej niż 5 godzin. Dla respondentów podana liczba godzin jest wystarczająca - 69\% uważa, iż dysponuje optymalnym czasem na sen.

\section{Natogi - profilaktyka}

- $87 \%$ respondentów zadeklarowało, że nie pali papierosów, zaś 13\% oświadczyło, że stosuje tego typu używki;

- w przypadku picia alkoholu odsetek osób nie spożywających tego trunku plasuje się na poziomie $40 \%$, natomiast $60 \%$ ankietowanych udzieliło odpowiedzi twierdzącej. Z czego najwięcej osób przyznało, że pije sporadycznie, $4-5$ razy w ciągu roku (41\%), 31\% alkohol spożywa w małych ilościach. Kolejna grupa, stanowiąca 13\% wszystkich badanych deklarujących picie, przyznała, że napoje alkoholowe spożywa przynajmniej raz w tygodniu, a pozostali (6\%) więcej niż 2 razy w ciągu tygodnia. Spożywanie nadmiernych ilości trunków wysoce procentowych stanowi przyczynę wielu jednostek chorobowych, głównie związanych z układem pokarmowym (Kuźnicka, 2017, s. 51-94);

- $63 \%$ respondentów przyznało, że głównym sposobem radzenia sobie ze stresem jest staranie, by unikać sytuacji stresogennych, $28 \%$ ankietowanych uznało, że przeżyte momenty stresujące odreagowuje spędzając czas z najbliższymi. Jedynie 3\% badanych zakomunikowało, że sięga po używki w postaci tytoniu oraz alkoholu. Pozostałe 6\% studentów seniorów w głównej mierze uciekało się do wszystkich powyżej przytoczonych sposobów walki ze skutkami stresu.

\section{Samoakceptacja}

- $86 \%$ badanych posiada poczucie, że żyje pełnią życia, akceptując siebie wraz ze swoimi zaletami i wadami (96\%) oraz mają rodzinę i wielu przyjaciół, na których mogą liczyć (91\%). Brak poczucia pełni życia i szczęśliwości dotyczy $14 \%$ badanych. Dzieje się tak, ponieważ okres starzenia się niejednokrotnie powiązany jest z zakończeniem pracy zawodowej, zmianą swojego wizerunku, niekiedy także przybraniem tzw. maski starości oraz transformacją odgrywanych ról społecznych. Osoba starsza niezwykle aktywna w okresie młodości nie potrafi pogodzić się z postępującymi skutkami procesu starzenia się. 


\section{Konkluzje i rekomendacje}

1. Zestawione powyżej dane statystyczne dają podstawę do dalszych prac projektowych, których celem będzie skonstruowanie ramowego programu kształcenia, adekwatnego do oczekiwań studentów, ale i wpisania się lokalnego środowiska w działania objęte celem strategicznym Narodowego Programu Zdrowia na lata 2016-2020 (Rozporządzenie Rady Ministrów z dnia 04.08.2016 w sprawie Narodowego Programu Zdrowia na lata 2016-2020, Dz. Urz. z dnia 2006 roku, poz. 1492). Jednym z celów operacyjnych tego programu jest promocja zdrowia i aktywnego starzenia się, w którym to przewiduje się prowadzenie polityki senioralnej, ukierunkowanej na jak najdłuższą aktywność społeczną, zawodową i rodzinną.

2. Programy kształcenia obejmować powinny treści z zakresu szeroko pojętej promocji zdrowia, ale w ujęciu interdyscyplinarnym i transdyscyplinarnym. Preferując holizm poznawczy, powinny propagować i utrwalać harmonię ciała - duszy - środowiska. Jest to niezwykle istotne w przekazie edukacyjnym w ogóle, a szczególnie, gdy odbiorcami są ludzie starsi.

3. Treści wykładów dotyczyć powinny także tych kwestii, które stanowią swoiste tabu, m.in. seksualności osób starszych oraz wypełniać luki informacyjne, zgodnie z zapotrzebowaniem słuchaczy (niewątpliwie jest to problematyka żywności i żywienia, aktywności ruchowej, umiejętności udzielania pierwszej pomocy, ale także aspektów prawnych systemu opieki zdrowotnej). Sugeruje się zatem intensyfikację działań w tej problematyce.

4. Biorąc pod uwagę efektywność kształcenia zajęcia powinny mieć nowoczesną obudowę multimedialną, ale także powinny być wspomagane materiałami informacyjnymi, także ze względu na często występujące odroczone efekty kształcenia.

5. Zrealizowana tematyka wykładów (m.in. z medycyny uzdrowiskowej) oraz wzajemna wymiana informacji spowodowała, iż 34\% badanych złożyło wnioski ubiegając się o sanatoryjne turnusy rehabilitacyjne, a $40 \%$ badanych zadeklarowało, iż w trosce o zdrowie zmieniło swoje zachowania na bardziej prozdrowotne, w zdecydowanej większości więcej spacerują i jeżdżą na rowerze.

6. Badana populacja, składająca się ze studentów uczelnianego UTW, generalnie ma wysokie poczucie dobrostanu zdrowia fizycznego oraz świadomość faktu, iż w dużej mierze zależy on od nich sa- 
mych. Deklarują więc podejmowanie zachowań, których atrybuty (od ćwiczeń fizycznych, zdrowe odżywianie, po sen) wskazują na troskę o własne zdrowie. Zróżnicowany jednak zakres wiedzy studentów-seniorów na temat zachowań prozdrowotnych oraz różnorodność podejmowanych zachowań nie zaskoczyła badaczy. Uzyskano cenną informację o preferencjach studentów w tym zakresie.

7. Zgromadzony materiał empiryczny nie wskazuje na bezpośrednią medykalizycję życia seniorów, aczkolwiek wierzą w nieograniczone możliwości medycyny. Chcąc uniknąć polaryzacji tematycznej i hermetyzacji środowiska należy z całą mocą rekomendować kontakty z innymi środowiskami, szczególnie cenne są spotkania międzypokoleniowe. Mają one ogromną wartość, także edukacyjną.

Proces starzenia się społeczeństw stał się faktem i najbardziej zaawansowany jest w Europie (WHO, 2012). Według danych z GUS w roku 2013 osoby w wieku 65 lat i więcej stanowiły 14,7\% populacji kraju, według przewidywań w 2035 roku będzie to 24,5\%, a w roku 2050 - 32,7\% (GUS, 2014). We wspomnianych materiałach WHO wskazuje się na konieczność redefinicji pojęć: zdrowie, bezpieczeństwo zdrowotne czy starzenie się. Musimy zatem wypracować taką ofertę programową, która spowoduje, iż życie seniorów nabierze cech transgresyjnych. „Nie dodawajmy lat do życia, ale życia do lat" (Sobieszczańska, 2017).

\section{Bibliografia}

Arendt A., Laszczyńska M., Bażdyło M. (2014), Ocena zachowań zdrowotnych mężczyzn po 40 roku życia, „Problemy Higieny i Epidemiologii”, 95(3).

Heszen I., Sęk H. (2007), Psychologia zdrowia, Wydawnictwo Naukowe PWN, Warszawa.

Kuźnicka J. (2017), Zachowania prozdrowotne studentów Uniwersytetu Trzeciego Wieku przy Uniwersytecie Medycznym we Wrocławiu, Wykorzystano elementy niepublikowanej pracy magisterskiej, wykonanej pod kierunkiem dr Żanetty Kaczmarek, Uniwersytet Medyczny we Wrocławiu.

Mróz J., Kaleta K. (2013), Struktura relacji $w$ rodzinie pochodzenia a zachowania prozdrowotne dorostych, „Problemy Higieny i Epidemiologii”, 94(2).

Muszalik M., Zielińska-Więczkowska H., Kędziora-Kornatowska K. i wsp. (2013), Ocena wybranych zachowań sprzyjających zdrowiu wśród osób starszych w oparciu o Inwentarz Zachowań Zdrowotnych Juczyńskiego w aspekcie czynników socjo-demograficznych, „Problemy Higieny i Epidemiologii”, 94(3). 
Ogińska-Bulik N., Zadworna-Cieślak M., Rogala E (2015)., Rola zasobów osobistych $w$ podejmowaniu zachowań zdrowotnych przez osoby $w$ wieku senioralnym, „Problemy Higieny i Epidemiologii”, 96(3).

Smoleń E., Gazdowicz L., Żyłka-Reut A. (2011), Zachowania zdrowotne osób starszych, „Pielęgniarstwo XXI Wieku”, 3(36).

Sobieszczańska M. (2016), Prewencja chorób serca, wykład dla studentów UTW we Wrocławiu z dnia 04.11.2016.

Syrkiewicz-Świtała M., Holecki T., Wojtynek E. (2014), Znaczenie mass mediów w promocji zdrowia, „Medycyna Ogólna i Nauki o Zdrowiu”, 20(2).

Tańska M., Babicz-Zielińska E., Przysławski J. (2013), Postawy osób starszych wobec zdrowia i żywności o działaniu prozdrowotnym, „Problemy Higieny i Epidemiologii", 94(4).

WHO, Good health adds life to years. Global brief for World Health Day.

Wojtasik W., Szulc A., Kołodziejczyk M. i wsp. (2015), Wybrane zagadnienia dotyczace wpływu wysiłku fizycznego na organizm człowieka, „Journal of Education, Health and Sport”, 5(10).

Woynarowska B. (2008), Edukacja zdrowotna, Wydawnictwo Naukowe PWN, Warszawa.

\section{Netografia:}

Główny Urząd Statystyczny. Portal informacyjny, dostępny na: http://stat.gov.pl/ (otwarcia wielokrotne, luty/kwiecień 2017).

Polskie Badania Internetu. Raporty i analizy. Polscy internauci, dostępny na: http:// pbi.org.pl/raporty/polscy-internauci/ (otwarty 23.04.2017).

Polskie Towarzystwo Kardiologiczne, http://www.ptkardio.pl (otwarcia wielokrotne, marzec/kwiecień 2017). 